\title{
Students' Grammatical Error Analysis in Speaking
}

\author{
Refa Anjeng Sari \\ An English Teacher of SMPN 1, Palembang, South Sumatra, Indonesia \\ refaanjangsari@gmail.com
}

\begin{abstract}
The purposes of this research were to find out the kinds of students' grammatical error, and to figure out the dominant kind of grammatical error in speaking. The research design was descriptive research. The participant of this research was students of State Islamic University in Palembang, South Sumatera. The purposive sampling method was used to choose 12 participants; three students was taken from category of high, medium, and low score in speaking class. The collection of data used documentation by recording student's speaking performance. The data were analyzed by using Linguistic Category Classification from Politzer and Ramirez. Based on the result of data analysis, 12 kinds of grammatical errors were found. The dominant kind of grammatical error was about number. The lowest percentages were about third person singular incorrectness and comparative adjective/adverb incorrectness.
\end{abstract}

Keywords: error analysis, grammatical error, speaking

$$
\begin{array}{r}
\text { Manuscript submitted: June 24, } 2018 \\
\text { Manuscript revised: September 3, } 2018 \\
\text { Accepted for publication: September, 17, } 2018
\end{array}
$$

\section{Introduction}

People use their own language to communicate and interact in different linguistics context. It means that the success in communication process leads us to be able to choose one language that can be used in daily life because language is a characteristic of human being. It plays an important role in human life because by using a language, people can express their ideas, emotion, and desire(Ariesca \& Marzulina, 2015). English has become one language which is used by most of people around the world and it plays an important role. As the effect of the globalization, English mastery becomes a requirement in all of work field, and most of the documents and information are served in English (Ardiansyah \& Djohar, 2012). In addition, most of the medium instruction in education environment and work environment are not use English (Haryanto, 2013). In Indonesia, English is mostly learned by students in school and university which the students have the variety background and different motivation to learn it (Arib, 2017). Pitaloka (2014) states that English learning in Indonesia is not really effective caused some problems like teacher-oriented center, limited of time allocation, textbook issue, and used of big class. It reflects that learning English is difficult for students.

In teaching learning English, the learners are expected to have the four skills in language. The language skills are listening, reading, writing, and speaking. However, some experts believe that speaking is more important than others. Louma (2004) identified that speaking is a meaningful interaction between people. The other expert, Cameron (2001) said that speaking is a crucial language skill used to express meanings. He implied that in ELT process concerning on speaking, the learners need to choose the appropriate words in expressing the meanings so that the listeners can understand their speaking clearly. Then, speaking is important skill to concern which has a lot of advantages. Loubazid (2012) also claimed that speaking skill becomes a demanded skill in the 
other language skills. Therefore, with speaking, students can improve their writing skill and develop their vocabulary and grammar.

In learning speaking, the students also need to understand the language components of English such as comprehension, grammar, vocabulary, pronunciation, and fluency. In relation to speaking, linguistic knowledge has essential roles for speaking skill. Indonesian people have the difficulties in mastering speaking skill because the daily language of Indonesian is not English. Robinson and Ellis (2008) stated that speaking is still considered as the most difficult skill to possessed by the majority of English learners, and they still do not have good competency in communicating in English. In Indonesia, English speaking skill of the student is still low. Reported in marketplus.co.id (May 21, 2016), English First (EF) centers stated that 46,5\% of Indonesian students has double lower speaking skill than their listening and reading skill. It really proves that speaking is difficult skill to be mastered and it is important to be concerned.

There are some difficulties that might be faced by EFL learner in speaking English. Loubazid (2012) describes those difficulties are caused by lack of vocabulary, pronunciation, and grammar. Since English is recognized as a foreign language in Indonesia, it makes Indonesian learners are difficult to speak English fluently. Mukminin et al. (2015) revealed that the student's speaking skill is low in Indonesia. It is caused by the lack of vocabulary and grammar knowledge. Grammar knowledge is one of the most important aspects of being a professional in speaking skill. Based on teacher's perception, both teachers and students invariably face serious difficulties with regard to EFL grammar instruction (Al-Mekhlafi \& Nagaratnam, 2011). English learning in Indonesia still focuses on the rules of English grammar. English grammar is different from the grammar in Indonesian language. Based on the explanation above, speaking is important skill, but the EFL learners have grammatical problems to master speaking skill. In addition, Astrid (2011) states that Indonesian students sometimes are easy to mention the rule of English grammar but when they deal with applying that skill in speaking, it will be so difficult for them.

An error analysis can be an answer as feedback to EFL learners. They can notice the grammatical errors that commonly happen when they are speaking. It is also for improving their speaking skill. Foreign language learners should also familiarize themselves to language learning strategy in order to be able to better self-manage their language learning (Kamil, Suhaimi, Hartono, \& Vintoni, 2017). If the students know the errors which they made, it will make them able to choose the best learning strategies of English learning. According to Corder (1981), the aims of Error Analysis is to figure out what the learners understand and do not understand and to make teacher provide the learners not only with the information that his hypothesis is wrong, but also, importantly, with the right source of information or data for him to form a more sufficient concept of a rule in the target language. Thus, the interview as the preliminary study had been conducted for the students of State Islamic University in Palembang. Most of the students claimed that speaking was difficult skill especially about the vocabulary and grammar which was used in their speaking performance. The students also said that sometimes they used the wrong grammar when speaking such as past tense became present tense. They did not notice when they spoke with wrong grammar continuously, and they just realized it after the conversation or speaking performance was over. The student also did not know whether they did mistakes or errors when they spoke.

Several researchers have previously explored about error analysis in EFL and ESL. Amara (2015) found that the Arabic speakers in this study committed a great number of errors due to L1 transfer. Hojati (2013) revealed the advanced-level Iranian EFL students have some linguistic problem which is considered as error especially the ones corresponding to grammar and pronunciation. In addition, Tarawneh and Almomani (2013) indicated that most of Jordanian English students are unable to speak English accurately although many of them have learned a great deal of grammatical knowledge and vocabulary. 
Based on explanation above, it indicates that grammatical error analysis is crucial issue and necessary to be searched. The preliminary study also shows that students think speaking is important, and it is hard to be mastered. They also realize that they have problem with grammar while speaking, and they also can not notice whether they do a mistake or error in their speaking performance. This research discusses grammatical error analysis in speaking of sixth semester students in English education study program. The problems in this study are to find out the kinds of grammatical error in students' speaking performance at State Islamic University in Palembang and to find out the dominant kind of grammatical errors in speaking performance of the students State Islamic University in Palembang.

\section{Literature Review}

\section{The concept of error}

Error is the systematic deviations done by learners who do not understand the rules of the target language. It happens repeatedly as an unconscious process. Error reflects a lack of underlying competence in the language they learn (Novita, 2014). Brown (2007) claimed an error as a deviation which can be noticed from the adult grammar of a native speaker. It reflects the interlingua competence of the learner. When a learner learns a foreign language, the errors made by him are an indication of his level proficiency. Whereas, mistake deals with a language performance. The learners have known the correct rules, but they are unable to perform their competence. Brown (2007) declares mistake is a lack of performance either a random guess or a 'slip' in that its failure to utilize known system correctly. Mistakes can be caused by slip of the tongue and physical condition, such as fatigue, lack of attention, and strong emotion (Novita, 2014). In addition, Scovel (2002) gives more explanation that people who make mistake or slip tongue, there will be selfcorrection but it's vice versa for people who do errors. Errors are caused by two sources of errors. Brown (2007) states the source of errors can be classified as follows: 1) Language transfer or interlingua interference; In this type, errors are caused by mother tongue interference. 2) Intralingua interference; This kind of errors occurs during the learning process of the second language at a stage when the learners have not really acquired the knowledge.

In classifying the errors, taxonomy is needed. Taxonomies of error refer to the classification of error according to certain criteria. Dulay, Burt, and Krashen (1982) suggest that there are four kinds of error taxonomy as follow; 1) Linguistic Category Classification: this type of taxonomy carries the specification of error in terms of linguistic categories. Linguistic category involves the language levels of the error, its class, its rank, and its grammatical system. 2) The Surface Structure Taxonomy: this taxonomy is assigned based on the ways surface structures are altered. This is suitable for analyzing error in Writing. 3) Comparative error; this is a taxonomy of error based on comparison between 12 structures errors and certain other types of construction. 4) Communicative Effect Taxonomy; it deals with error from the perspective of their effect on the listener and error. It deals with distinguish between errors that seems to cause miscommunication and those that do not.

In this research, I focused on grammatical error. Grammatical error is the error in combining words into larger unit, such as phrases, clauses, and sentences. Grammatical error can also be defined as the errors at morphological and syntactical levels. Morphological error is the error which involves a failure to comply with the norm in supplying any part of word classes, noun, verb, adjective, adverb, and preposition (James, 1998). Syntactical errors are errors that affect texts larger than word, namely phrase, clause, sentence, and paragraphs (James, 1998). Syntactical errors cover phrase structure error, clause error, and sentence error.

In analyzing error, it needs to follow the steps of error analysis. Yang (2010) stated that Error Analysis is the process of determining the incidence, nature, causes and consequences of unsuccessful language. Another definition of error analysis is given by Brown (2007). He defines 
error analysis as a process to observe, analyze, and classify the deviations of the rules of the second languages and then to reveal the system operated by learner. In addition, improving the quality of English teaching and learning process means the educational policymaker, curriculum creator, teachers should work together to evaluate, improve and redesign English teaching and learning curriculum (Azkiyah, \& Mukminin, 2017). It is needed to know the problems in teaching and learning process, so error analysis can be one of the tools in reviewing the problems. Corder (1981) explains "studying learner's errors serves two major purposes: (1) it provides data from which inferences about nature of language learning process can be made; and (2) it indicates to teachers and curriculum developers which part of the target language students have most difficulty producing correctly, and which error types detract most from learner's ability to communicate effectively", (p. 11).

\section{The concept of speaking}

Speaking is an interaction among people. Form and meaning of speaking are dependent on the context in which is occurs and speech is unpredictable (Dounough \& Shaw, 1993). Cameron (2001) stated that speaking is an active use of language to express meanings which can make other people understand. He implies that in ELT process concerning on speaking, the learners need to choose the appropriate words in expressing the meanings so that the listeners can understand their speaking clearly.

Learning a new language is an overarching experience that involves the whole person: physically, cognitively, and emotionally. In this experience, language learners fluctuate between an understanding of themselves as speakers of their first language (L1) and their awareness of themselves as learners of a second language (L2), of how they 'identify' themselves (Sa'd, 2017). When people are speaking, they need an awareness of using and switching their first and second language. That is why speaking in English can be difficult for EFL learner. It is not only about grammar but also the English vocabulary also reflects the target culture, which is unfamiliar for Indonesian EFL (Fikriyansyah, 2017).

Therefore, EFL learners, especially English education study program students who have English instruction for many years are unable to communicate in the target language, particularly among the four language skills. One of the most challenging language skills for learners is speaking. One of the possible reasons is that speaking requires complex skills, not merely conveying ideas verbally (Abrar et al. 2018). Speaking is also a medium through which many languages is learnt, and which for many is particularly conducive for learning. Mukminin et al. (2015) declare "many people think that mastering speaking abilities is the ultimate goal of acquiring a foreign or second language and the other skills are owed by its significance", (as cited in Novita, 2017, p 10). Zhang (2009) claimed that speaking is the most difficult skill for the majority of English learners because they do not have good competency in speaking ability. There are a lot of factors based on Ur (1996) that cause difficulty in speaking. The areas are inhibition, nothing to say, low or uneven participation, and Mother-tongue use. In addition, Gunawan (2017) states non-linguistic factor such as Selfesteem also had essential contribution in student's success in speaking achievement.

\section{Methods}

\section{Research design and Subjects of the study}

This study used descriptive research to describe the kinds of grammatical errors and to show the dominant error made by English Education study program students. The subject of the research was students of sixth semester of English education study program. They have taken all of language skill subjects including speaking course and grammar course. Therefore, the sixth semester students were chosen to know the success in teaching and learning process especially in those 
subjects above. I chosed the sampling by using purposive sampling method. Sixth semester students consisted of four classes. I just took three students from each class as the sample and they had the high, the medium, and the low score of speaking course. The way of choosing the students was based on the grade supported by Fraenkel et al. (2012). The total of samples in this study was 12 students.

\section{Data collection}

In collecting the data, I used documentation. Documentation in this research is the result of the recording of student's speaking performance. The subject was asked to talk for 3-5 minutes about themselves, their daily routine and about life in Indonesia or in the local area where they lived. The topic consisted of several points which were; 1) Place where they lived, 2) Knowledge of languages they had, 3) Things they liked, 4) Habits they had, 5) What Indonesian people like. This topic was adapted from Amara (2015). After recording, there was transcription process that made researcher easier to analyze the data. The process of transcription here was the researcher wrote all of the words and sentences which produced by students in their speaking performance.

\section{Data analysis}

In analyzing the data, I used error analysis method. This method involved collection of sample errors, identification of errors, and description of errors. This was collecting the data that would be processed and analyzed. In this research, the collection of the data was obtained through documentation. The documentation here was the recording of student's speaking performance. Then, the student's speaking performance was transformed into transcription, so it could be continued to the next process. In identification error process, I transcribed their speaking performance and analyzed the errors, mistakes, and normal sentences. Then, I compared the sentences contained errors with the correct sentences in target language.

This part was for classifying type of error. It could be done after I know and decide the errors, mistakes, and normal sentence. After I identified the errors the next step was I determined the type of the errors. Describing or classifying error had been done by using Linguistic category classification by Politzer and Ramirez (as cited in Dulay et al., 1982, p. 146-148). This taxonomy was the only taxonomy which separating error based morphology and syntax level, and those levels consider as a grammatical level. Since I used Linguistic category classification, the finding form focused on determining morphological and syntactical error. In finding the dominant of error, the percentage of errors from each category was also counted to answer second research problem. I used formula adapted from Fraenkel et al. (2012) stated as follows:

$\mathrm{P}=\frac{N 1}{\sum_{n}} \times 100 \%$

\section{Establishment of trustworthiness}

To build the trustworthiness, I used triangulation. In this research, I used investigator triangulation. This type of triangulation was done by asking expert or other researcher and investigator for rechecking the credibility of the data gained from the research after the data analysis was finished. The result of analysis was also rechecked by three lecturers of English. In addition, Moleong (2014) states the process of rechecking the data by experts means that the implementation of investigator triangulation is conducted.

\section{Findings}

The data of the research was gathered from student's speaking performance and the recording had transformed into transcript form. Then, the types of grammatical error was analyzed by using Linguistic Category Classification which introduced by Politzer and Ramirez (as cited in Dulay et al., 1982). The results are presented as follows: 
Table 1. Errors in Linguistic Category Classification

\begin{tabular}{lcc}
\hline \multicolumn{1}{c}{ Types of Error } & Frequency & Percentage \\
\hline Third person singular incorrectness & 1 & $2 \%$ \\
Comparative adjective/adverb & 1 & $2 \%$ \\
incorrectness & 2 & $4 \%$ \\
Determiners & 3 & $5 \%$ \\
Nominalization & 15 & $25 \%$ \\
Numbers & 2 & $4 \%$ \\
Use of pronouns & 7 & $12 \%$ \\
Use of preposition & 6 & $10 \%$ \\
Omission of verb & 5 & $8 \%$ \\
Use of progressive tense & 7 & $12 \%$ \\
Agreement of subject and verb & 5 & $8 \%$ \\
Verb-and-verb construction & 5 & $8 \%$ \\
Some transformations & 60 & $100 \%$ \\
$\quad$ Total & & \\
\hline
\end{tabular}

\section{Discussion}

There were twelve kinds of grammatical error which was found. At the morphological level, there were two types of error; error in third person singular incorrectness, and in comparative adjective. There were ten types at syntactical level. They were determiners, nominalization, number, pronouns, preposition, omission of verb, use of progressive tense, subject and verb agreement, verb-and-verb construction, and some transformations. There were two levels of grammatical error; morphological and syntactical error. Morphological error is the error which involves a failure to comply with the norm in supplying any part of word classes (James, 1998). The first kind at morphological level was third person singular incorrectness with the subcategory of error the use of 's' in verb. The example of speaker's error was:

\section{"It also belps people in every part such as in education."}

This type of error occurred when the speaker failed to give 's' in verb with the subjects were the third person singular such as she, he, it, or name of person. The similar result was also identified by Mardijiono (2003) which found 18 errors related to this type, and Ratnah (2013) found 3 cases of omitting s/es in present tense. The second kind error at morphological level was comparative adjective with the subcategory was the use of more $+e r$ in adjective and adverb. The comparative form of an adjective is used for comparing two people or things, to express the fact that one has a higher degree of a quality than the other. The example of speaker's error in this research was:

\section{"We just need to use English every day to practice and make our language ability more fluent and Aaaaa. more fluencer I mean and I really like too."}

The error from that sentence was the use of more + er at the phrase 'more fluencer' intead of 'more fluent'. In addition, Yunita (2014) did similar research related to error analysis in comparative degree. She found that Indonesia's students had high frequency of error due to forming comparative and superlative degree. In syntactical level, there were ten types of error. Syntactical errors were errors that affect texts larger than word, namely phrase, clause, sentence, and paragraphs (James, 1998). Syntactical errors covered phrase structure error, clause error, and 
sentence error. The first, it's error in using determiners, and the subcategory types are omission of the article. The example of the error was:

"He is ... honest public worker."

which in this sentence the speaker omitted the determiners 'an'. Moreover, in another research, Hojati (2013) found that error in determiners by Iranian EFL is one of three types of error which had high frequency. The reason is clear because the students who speak English as foreign language will have problem with rules of English which does not exist in their language. The second kind of error at syntactical level was nominalization. Taher (2015) claims that gerund, verbal noun, and deverbal noun are grammatical terms related to nominal formed from verbs or it is known also as nominalization. The subtype of error found in this research was stem word instead of the use of gerund (- ing form), for example:

"I love spend all of my time to watch movie" and I like cook, eat, watching, travelling, moving anywhere.

The error occurred because the student did not use gerund after the word 'like' in this sentence especially at the words 'cook' and 'eat'.

Next, the highest frequency of error was error in numbers. There were two subcategories found in this research. They were substitution of singular instead of plurals, and substitution of plurals instead of singular. This type occurred when the speaker did not put 's' or 'es' for plural words or phrase well and vice versa. It is related to singular and plural noun in English. The example of student's error was

"It means that we know about many culture" which the suggested correction is "it means we know about many cultures".

As the highest frequency, this result is also supported by the research from Mardijiono on 2003. He made error analysis with the combination of linguistic category classification and surface strategy as the taxonomies. He revealed more than thirty errors in number that was done by Indonesian advanced learner. The fourth kind of error was the use of pronoun. There were two subcategories found. They were the omission of the subject pronoun and subject pronoun used as redundant element. Amara (2015) states that a pronoun is a word that takes the place of a noun. Pronouns are used to make sentences less weighty and less repetitive. The example of student's speaker error was:

"I wake up in the morning and then we go to campus,....study and met with our friend and ....make some.."

This error occurred when the speaker did not put the pronoun before verb. The percentage was 4 $\%$ which is quiet low. In relation to the result of the research, many researchers have also found that errors in pronoun are still done by EFL students in speaking or oral performance (Amara, 2015; Chang, Mahadir, \& Thing, 2010; Hojati, 2013; Mardijiono, 2003). The fifth type of error was the use of preposition. The subcategories of error were the omission of preposition and misuse of preposition. The example was:

\section{"And then people Indonesia also."}

The sentence missed the preposition 'of. Chang, Mahadir, \& Thing (2010) did similar research which revealed 11 types of error including proposition. The difference was in preposition. It became the type with average percentage, but it was vice versa in their research. They found that 
preposition was the highest percentage of error done by university students in their oral performance. They also stated that based on a linguistic description of the errors, preposition is the most difficult for the less proficient students at university level. The sixth kind of error was omission of verb, and this occurred at verb phrase level. The subcategory of this kind was omission of to be. The example is:

\section{"We ..... from different place and area, and "T interested the movie because."}

It can be seen clearly that the speaker did not use 'are' which is needed to complete the sentence. Alahmadi (2014) in his research also discussed grammatical error analysis that the students made errors in this kind at least 13 times during their speaking performance”, (p. 94). In addition, English learners usually have problem and difficulty especially at early stages in applying the rule of English copula, "Copula(tive) is a term used in grammatical description to refer linking verb (Taher, 2009). Linking verb refers to 'to be' in this research. The next kind of error was the use of progressive tense. All of the subcategory in this type was found from the result of student's speaking test. They were the omission of be. The example of student's speaking error was:

$$
\text { "they ...... also following that and I think enough." }
$$

which is clearly seen that there was no to be 'are' for completing the sentence. This result is also supported with the research done by Mardjiono (2003) and Ratnah (2013) who stated that errors in using progressive tense still occurred. The eighth kind of error was subject and verb agreement. There were two subtypes of error, and those were disagreement of subject and number and disagreement of subject and tenses. Amara (2015) claimed that subjects and verbs must agree with one another in number (singular or plural). Thus, if a subject (the person or thing doing the action) is singular, its verb must be singular. If a subject is plural, its verb must be plural. The example in this research was:

\section{"If someone have other thing."}

In this sentence the verb was "have" instead of 'has'. Errors in subject and verb agreement are also identified by Amara (2015). She found that the total of error in this type was 78 from 711 errors. Chang, Mahadir, and Thing (2010) found errors in this type was 55 from 779 errors. Moreover, Heryati, Makmur and Sucipto (2017) revealed that errors in verb-tense done by English education study program students in one University in Jambi, had the highest percentage (508\%). Verb-tense is also the part of error in the subject and verb agreement. Then, the next kind of error was verb and verb construction. The subcategory which dominantly found was in the form of embedding of a noun-and-verb construction in another noun-and-verb construction. The percentage of this type was $8 \%$. The example was:

\section{"It's actually I have so many habits but I tell you about maybe two babit that I think is very} always I do every".

The speaker used many verbs in one sentence without clear connector, and word order was also incorrect. The last kind of error was some transformations. The subcategory was the formation of no or not without the auxiliary do. The example of the error was:

\section{"In the past Indonesian people not really care about it."}

The speaker tried to make negative sentence but there was the auxiliary 'did' before the word 'not'. The formation of no or not was without the auxiliary did. This subtype was also found by Mardijiono 
(2003) in his research. He stated that the errors in transformation became predominant error with the percentage was $53.57 \%$ viewed from linguistic category classification.

The percentage of error was calculated to know the dominant type of error. In this research, the highest percentage of grammatical error was number which is categorized as syntactical error with the percentage is $25 \%$. As the highest percentage, the error in number can be concluded as the dominant error which was done by the sixth semester English education study program students. The subcategories of error in this type were substitution of singular instead of plurals and Substitution of plurals instead of singular. In addition, Alahmadi (2014) indicated that number or misuse of singular and plural noun are the most common grammatical errors among Arabian EFL learners. It proves that this type is one of the difficult parts of grammar when the EFL students use it in speaking performance.

\section{Conclusionand Recommendations/Implications}

The finding showed that there were twelve kinds of grammatical error which had been found. At the morphological level, there were three types of errors and in syntactical level, there were ten types of error. It can be concluded that the grammar was still a problem in speaking especially the errors in numbers as the highest frequency. Errors need to be handled; otherwise, they will become fossilized. EFL teachers should be aware of what is going on in the field of Error Analysis and keep a keen eye on the related theories. This research also can be referencing points to review the curriculum for speaking skill lesson at university level especially English education study program.

\section{References}

Abrar, M., Mukminin, A., Habibi, A., Asyrafi, F., Makmur, M., \& Marzulina, L. (2018). "If our English isn't a language, what is it?" Indonesian EFL student teachers' challenges speaking English. The Qualitative Report, 23(1), 129-145. Retrieved from http://nsuworks.nova.edu/tqr/vol23/iss1/9

Al-Mekhlafi, A. M., \& Naratnam, R. P. (2011). Difficulties in teaching and learning grammar in EFL context. International Journal of Instruction, 4(2), 69-92. Retrieved from https:// files.eric.ed.gov/fulltext/ED522689.pdf

Alahmadi, N. S. (2014). Errors analysis: A case study of saudi learner's English grammatical speaking errors. Arab world English journal, 5(4), 84-98. Reetrieved from http://connection.ebscohost.com/c/casestudies/100190182/errors-analysis-case-study-saudi-learners-english-grammatical-speaking-errors

Amara, N. (2015). Errors correction in foreign language teaching.The Online Journal of New Horizons in Education, 5(3), 58-68. $\quad$ Retrieved from http://www.tojned.net/journals/tojned/articles/v05i03/v05i03-07.pdf

Ardiansyah, W. \& Djohar, A. (2012). Pengembangan model pembelajaranmembacauntukmeningkatkankemampuanmembacapemahamandalampembalajaranbahas ainggris: Studi pada mahasiswa Politeknik di Palembang. Ta'dib: Journal of Islamic Education, 17(2), 161167. Retrieved from http://jurnal.radenfatah.ac.id/index.php/tadib/article/view/30/25

Arib, A. W. (2017). Do family backgrounds control students' motivation and achievement in learning a foreign language? The case of one Islamic senior high school in Jambi.Ta'dib: Journal of Islamic Education 22(1), 1-38. Retrieved from http://jurnal.radenfatah.ac.id/index.php/tadib

Ariesca, \& Marzulina, L. (2016). Teaching reading narrative text by using window notes strategy to the eighth grade students of SMP Muhammadiyah 4 Palembang. Jurnal Pendidikan dan Pengajaran, 3(1), 2332.

Astrid, A. (2011). Pembelajaran tata Bahasa Inggris secara komunkatif dengan penyajian induktif dan pengintegrasian keterampilan berbahasa: Studi kasus di kelas Bahasa Inggris di IAIN Raden Fatah Palembang. Ta'dib, 16(2), 175-208. Retrieved from http://jurnal.radenfatah.ac.id/index.php/tadib/article/view/60/55.

Astrid, A. (2012). PengintegrasianpendidikankarakterdalamaktivitaspembelajaranBahasaInggris.Ta'dib: Journal of Islamic Education, 17(2), 271-283 retrieved from http://jurnal.radenfatah.ac.id/index.php/tadib/article/view/35/30 
Azkiyah, S. N., \&Mukminin., A. (2017). In search of teaching quality of EFL student teachers through teaching practicum: Lessons from a teacher education program. C.E.P.S. Journal, 7(4), 105-123. Retrieved from https://online-journal.unja.ac.id/index.php/irje/issue/archive

Brown, H. D. (2007). Principles of language learning and teaching (5th ed.). New York, NY: Pearson Education Inc.

Cameron, Lynne. (2001). Teaching language to young learners. Cambridge, England: Cambridge University Press

Corder, S. (1981).Error analysis and interlanguage. Oxford, England: Oxford University Press.

Dulay, H., Burt, M., \&Krashen, S. (1982).Language two. New York, NY: Oxford University Press.

Fikriyansyah. (2017). Local and target language culture proportion in English text book "English on Sky (EOS) 2" and "When English Rings Bell (WERAB) VIII". Jurnal Pendidikan dan Pengajaran, 4(1), 10-17 retrieved from http://jurnal.radenfatah.ac.id/index.php/edukasi/issue/view/217

Fraenkel, J. R., Wallen, N. E., \& Hyun, H. H. (2012). How to evaluate research in education (8th ed.). New York, NY: McGraw-Hill.

Gunawan, J. (2017). The correlation between student's self-esteem and speaking achievement of undergraduate EFL students of English education study program of Islamic State University of Raden Fatah Palembang. Jurnal Pendidikan dan Pengajaran, 4(2), 1-10. Retrieved from http://jurnal.radenfatah.ac.id/index.php/edukasi/issue/view/217

Haryanto, E. (2013). Language Policy: Administrators and teachers' view on English as medium of instruction implementation in Indonesia. Journal of Education and Learning, 4(2), 48-57. Retrieved from https://online-journal.unja.ac.id/index.php/irje/issue/view/639

Hojati, A. (2013). An Investigation of errors in the oral performance of advanced-level Iranian EFL students. Mediterranean Journal of Social Sciences, 4(4), 171-176. Retrieved from www.mcser.org/journal/index.php/miss/article/4/4

James, C. (1998). Errors in language learning and use: Exploring error analysis. Massachuset, MA : Addison Wesley Longman Inc.

Kamil, D., Suhaimi., Hartono, R., \& Vintoni, A. (2017). TEFL students' language learning strategies: The case of one state Islamic institute in Indonesia. Ta'dib: Journal of Islamic Education, 22(2), 70-76. Retrieved fromhttp://jurnal.radenfatah.ac.id/index.php/tadib/article/view/64/59

Loubazid, M. (2012).Exploring the difficulties facing EFL students' participation in oral expression course (Master thesis).University of Biskra, Biskra, Algeria. Retrieved from http://dspace.univbiskra.dz:8080/jspui/bitstream/

Luoma, S. (2004). Assessing speaking. Cambridge, England: Cambridge University Press.

Mardijiono, J. J. (2003). Indonesian EFL advanced learners' grammatical errors. Jurnal Petra, 5(1), 67-90.

Moleong, L. J. (2014). Metodologi penelitian kualitatif. Bandung, Indonesia: PT Remaja Rosdakarya.

Mukminin,A., Noprival., Masbirorotni., Sutarno., Arif, N., \& Maimunah. (2015). EFL speaking anxiety among senior high school students and policy. Journal of Education and Learning, 9(3), 217-225.

Novita, R. (2014). An analysis of grammatical errors in the $1^{\text {st }}$ year student's writing at English department, Andalas University. Vivid journal, 3(2), 1-15. Retrieved from jurnalvivid.fib.unand.ac.id/index.php/vivid/article/view/16

Novita, T. (2017). Student's English speaking skill and activation method: The case of one senior high school. Jurnal Pendidikan dan Pengajaran, 4(2), 10-17 retrieved from http://jurnal.radenfatah.ac.id/index.php/edukasi/issue/view/222

Pitaloka, N. L. (2014). Developing interactive multimedia with local-content-based narrative texts for grade eight. Lingua: Jurnal Bahasa \& Sastra, 15(1), 1-22. Retrieved from http://ejournal.unsri.ac.id/index.php/lingua/article/view/1994/834

Ratnah.(2013). Error analysis on tenses usage made by Indonesian students. Journal of Education and Practice, 4(6), 159-19. Retrieved from https://indraratnamoeliiya.files.wordpress.com/2015/03/error-analysisof-students-english-writing_indra-ratna.pdf.

Robinson, P, Ellis, N. (2008). Handbook of cognitive linguistics and second language acquisition. New York, NY: Taylor \& Francis.

Sa'd, S. H. T. (2017). Foreign language learning and identity reconstruction: Learners' understanding of the intersections of the self, the other and power. C.E.P.S. Journal, 7(4), 13-35. Retrieved from https://online-journal.unja.ac.id/index.php/irje/issue/archive

Scovel, Thomas. (2002). Psycholinguistic. New York, NY: Oxford University Press. 


\section{Edukasi}

Taher, I. I. (2015). The problematic forms of nominalization in English: gerund, verbal, noun, and deverbal noun. English Linguistic Research, 4(1), 30-40. Retrieved from www.sciedu.ca > Home >Vol 4

Tarawneh, R. T. \& Almomani, I. M. (2013). The spoken errors and mistakes committed by senior English students at Princess Alia University college. Theory and Practice in Language Studies, 3(3), 497-502. Retrieved from www.academypublication.com/issues/past/tpls/vol03/.../14

Ting, S. H., Mahadhir, M., Chang, S. L. (2010). Grammatical errors in spoken English of university students in oral communication course. Journal of Language Studies, 10(1), 53-70. Retrieved from http:/ / ejournal.ukm.my/gema/article/view/126.

Ur, P. (1996). A course in language teaching. Cambridge, England: Cambridge University Press.

Yang, W. (2010). A tentative analysis of errors in language learning and use. Journal of Language Teaching and Research, 1(3), 266-268. Retrieved from www.finchpark.com/courses/tkt/Unit 11/errors.pdf

Yunita, M. (2014). An analysis on the student's errors in using degrees of comparison of adjective (Undergraduate thesis, UIN Syarif Hidayatullah, Jakarta , Indonesia). Retrieved from http:/ /library.uinsyarifhidayatullah. ac.id/tarbiyah/pdf

Zhang, S. (2009). The role of input, interaction, and output in the development of oral fluency. English Language Teaching, 2(4), 91-100. Retreved from https:/ / files.eric.ed.gov/fulltext/EJ1083691.pdf 